\title{
Levels of Evidence in the Plastic Surgery Literature: A Citation Analysis of the Top 50 'Classic' Papers
}

\author{
Kenneth M Joyce ${ }^{1}$, Cormac W Joyce ${ }^{1}$, John C Kelly ${ }^{2}$, Jack L Kelly ${ }^{1}$, Sean M Carroll ${ }^{3}$ \\ ${ }^{1}$ Department of Plastic and Reconstructive Surgery, Galway University Hospital, Galway; ${ }^{2}$ Department of Orthopaedic Surgery, St. Vincent's \\ University Hospital, Dublin; ${ }^{3}$ Department of Plastic and Reconstructive Surgery, St. Vincent's University Hospital, Dublin, Ireland
}

Background The plastic surgery literature is vast, consisting of a plethora of diverse articles written by a myriad of illustrious authors. Despite this considerable archive of published material, it remains nebulous as to which precise papers have had the greatest impact on our specialty. The aim of this study was to identify the most cited papers in the plastic surgery literature and perform a citation analysis paying particular attention to the evidence levels of the clinical studies.

Methods We identified the 50 most cited papers published in the 20 highest impact plastic surgery journals through the Web of Science. The articles were ranked in order of number of citations acquired and level of evidence assessed.

Results The top 50 cited papers were published in six different journals between the years 1957 and 2007. Forty-two of the papers in the top 50 were considered as level IV or V evidence. No level I or II evidence was present in the top 50 list. The average level of evidence of the top 50 papers was 4.28 .

Conclusions In the plastic surgery literature, no positive correlation exists between a high number of citations and a high level of evidence. Anatomical reconstructive challenges tend to be the main focus of plastic surgery rather than pathologic diseases and consequently, papers with lower levels of evidence are relatively more valuable in plastic surgery than many other specialties.

\section{Keywords Bibliometrics / Classical article / Plastic surgery}

Correspondence: Kenneth M Joyce Department of Plastic and Reconstructive Surgery, Galway University Hospital, Galway, Ireland Tel: $+353-879654586$

Fax: +353-91542000

E-mail: kennethjoyce1@gmail.com

Received: 31 Jul 2014 • Revised: 6 Apr 2015 • Accepted: 23 Apr 2015

pISSN: 2234-6163 • elSSN: 2234-6171 • http://dx.doi.org/10.5999/aps.2015.42.4.411 • Arch Plast Surg 2015;42:411-418

No potential conflict of interest relevant to this article was reported.

\section{INTRODUCTION}

Over the years a large volume of work has been published in the field of plastic surgery, however the impact of a given paper on the specialty remains unknown. Articles published in the plastic surgery literature reflect its evolution in time. Evidence-based medicine dictates that clinical decision making be guided by high-quality research and evidence [1]. The growth and direction of plastic surgery as a specialty has been driven by the pub- lication of the work of peers.

The number of citations a publication receives echoes its relevance to a given subject. An author cites a paper in an effort to acknowledge the previous work of others in producing valuable evidence. It is a reflection on the journal also, as the more times an article is cited, the greater the impact factor (IF) of the journal. The IF of a journal is calculated for a given year, by obtaining the average number of citations received per article published in that journal during the two preceding years. The IF is viewed 
as the best method of assessing the overall merits of a journal, despite there being well-described flaws with the system [2]. Citation analysis is a bibliometric process that describes the means of analysing the citation history of published papers [3]. The methologic quality and relevance of published studies are the main factors that promote their citation and affect the impact factor of a journal.

Multiple surgical specialties, including general surgery [4], urology [5], and orthopaedics [3], have used citation rank lists to determine the impact of articles and journals within the specialty. The aim of this study was to assess the contribution of twenty plastic surgery journals to classic papers in plastic surgery based on citation numbers, with further analysis of level of evidence of these classic papers.

\section{METHODS}

To identify the most frequently cited articles published in the plastic surgery literature, we selected the twenty highest impact journals dedicated to plastic surgery and its subspecialty areas. Three of the authors (K.M.J., C.W.J., and J.C.K.) independently identified the plastic surgery journals with consensus. All articles published from 1945 to date in twenty plastic surgery journals were included in our search (Table 1). The database of the Science Citation Index (SCI) of Institute for Scientific Information (ISI) was used for identifying the most-cited publications in all these plastic surgery journals. The SCI was accessed online

\section{Table 1. Journals included in our search of most-cited} papers

\begin{tabular}{l}
\hline Journal name \\
\hline Plastic and Reconstructive Surgery \\
Journal of Plastic Reconstructive \& Aesthetic Surgery \\
British Journal of Plastic Surgery \\
Aesthetic Plastic Surgery \\
Journal of Plastic Surgery and Hand Surgery \\
Annals of Plastic Surgery \\
Aesthetic Surgery Journal \\
Operative techniques in Plastic and Reconstructive Surgery \\
Archives of Facial Plastic Surgery \\
Microsurgery \\
Clinics in Plastic Surgery \\
Scandinavian Journal of Plastic and Reconstructive Surgery and Hand Surgery \\
Canadian Journal of Plastic Surgery \\
Archives of Plastic Surgery \\
European Journal of Plastic Surgery \\
Journal of Craniofacial Surgery \\
Journal of Reconstructive Microsurgery \\
Ophthalmic Plastic and Reconstructive Surgery \\
JAMA Facial Plastic Surgery \\
Seminars in plastic surgery
\end{tabular}

through the Web of Knowledge collection of databases by two of the authors (K.M.J. and C.W.J.) independently and there was $100 \%$ concordance.

The top 50 most-cited articles were tabulated and further analysed according to level of evidence, article type, origin of publication, year of publication and subspecialty. The country of origin was defined by the address provided by the first author. Each article was classified into levels of evidence on a scale of I to $\mathrm{V}$ as per previously described guidelines by the Oxford Centre for Evidence-Based Medicine [6]. Level I evidence consisted of randomised clinical trials or meta-analysis of randomized clinical trials. Level II evidence consisted primarily of cohort studies. Level III evidence consisted of case-control studies and compared two or more groups where the data were collected retrospectively. Level IV evidence consisted of case series. Level V evidence consisted of case reports and basic science articles.

Ranking articles based on number of citations alone creates a bias towards older articles purely because of their longer citable period. In an effort to limit this bias we evaluated the citation index of each of the top 50 articles, defined as the mean number of times they were cited per year up until sixteen years after publication. For articles that had been published within the last sixteen years, the total number of citations since publication were divided by the number of years since publication. Sixteen years has previously been described as the critical citable period when any given paper will acquire the majority of its citations [7].

\section{RESULTS}

The 50 articles are listed in Table 2 [8-57] in descending order based on total number of citations. The mean number of citations of the top 50 articles was 859 (range, 449-2,615). The most frequently cited paper was by Mulliken and Glowacki [8] in 1982 with 2,615 citations which classified vascular malformations in children. The earliest publication was in 1957 by Neumann [41] and the most recent publication was in 2007 Rigotti et al. [55]. The most frequent decade represented in the list was the 1980's with 19 papers from this time period (Table 3). Despite the fact that 20 journals were included in our search only five journals were represented in the top 50 (Table 4). Plastic and Reconstructive Surgery Journal published $72 \%$ (36/50) of the top 50 articles.

Forty-two of the papers in the top 50 were considered as level IV or V evidence (Table 5) consisting of case series, bench research, expert opinion and first principles. The average level of evidence was 4.28. No paper in the top 50 was of level I, II evidence. The majority (36/50) of articles contained evidence of experimental or therapeutic intervention. Our analysis of the content of the top 50 articles demonstrated that the most com- 


\begin{tabular}{|c|c|c|c|}
\hline Rank & Article & $\begin{array}{l}\text { No. of } \\
\text { citations }\end{array}$ & $\begin{array}{l}\text { Citation } \\
\text { index }\end{array}$ \\
\hline 1 & $\begin{array}{l}\text { Mulliken and Glowacki. "Hemangiomas and vascular malformations in infants and children: a classification based on endothelial characteristics." } \\
\text { Plast Reconstr Surg (1982) [8] }\end{array}$ & 2,615 & 16.2 \\
\hline 2 & Argenta and Morykwas. "Vacuum-assisted closure: a new method for wound control and treatment: clinical experience." Ann Plast Surg (1997) [9] & 1,869 & 110 \\
\hline 3 & $\begin{array}{l}\text { Morykwas et al. "Vacuum-assisted closure: a new method for wound control and treatment: animal studies and basic foundation." Ann Plast Surg } \\
\text { (1997) [10] }\end{array}$ & 1,764 & 105 \\
\hline 4 & McCarthy et al. "Lengthening the human mandible by gradual distraction." Plast Reconstr Sur (1992) [11] & 1,637 & 68.8 \\
\hline 5 & Branemark et al. "Intra-osseous anchorage of dental prostheses: I. experimental studies." Scand J Plast Reconstr Surg (1969) [12] & 1,596 & 2.8 \\
\hline 6 & $\begin{array}{l}\text { Masquelet et al. "Skin island flaps supplied by the vascular axis of the sensitive superficial nerves: anatomic study and clinical experience in the } \\
\text { leg." Plast Reconstr Surg (1992) [13] }\end{array}$ & 1,281 & 44.4 \\
\hline 7 & Taylor et al. "The free vascularized bone graft: a clinical extension of microvascular techniques." Plast Reconstr Surg (1975) [14] & 1,101 & 15.3 \\
\hline 8 & Hartrampf et al. "Breast reconstruction with a transverse abdominal island flap." Plast Reconstr Surg (1982) [15] & 1,049 & 16.3 \\
\hline 9 & $\begin{array}{l}\text { Taylor, G. lan, and J. H. Palmer. "The vascular territories (angiosomes) of the body: experimental study and clinical applications." Br J Plast Surg } \\
\text { (1987) [16] }\end{array}$ & 949 & 16.3 \\
\hline 10 & Hidalgo. "Fibula free flap: a new method of mandible reconstruction." Plast Reconstr Surg (1989) [17] & 936 & 25.1 \\
\hline 11 & Ariyan. "The Pectoralis Major Myocutaneous Flap A Versatile Flap for Reconstruction in the Head and Neck." Plast Reconstr Surg (1979) [18] & 900 & 22.1 \\
\hline 12 & Godina. "Early microsurgical reconstruction of complex trauma of the extremities." Plast Reconstr Surg (1986) [19] & 832 & 17.8 \\
\hline 13 & Dahlin et al. "Healing of bone defects by guided tissue regeneration." Plast Reconstr Surg (1988) [20] & 754 & 22.7 \\
\hline 14 & Bain et al. "Functional evaluation of complete sciatic, peroneal, and posterior tibial nerve lesions in the rat." Plast Reconstr Surg (1989) [21] & 739 & 14.7 \\
\hline 15 & Bakamjian. "A two-stage method for pharyngoesophageal reconstruction with a primary pectoral skin flap." Plast Reconstr Surg (1965) [22] & 719 & 14.4 \\
\hline 16 & Wei et al. "Have we found an ideal soft-tissue flap? an experience with 672 anterolateral thigh flaps." Plast Reconstr Surg (2002) [23] & 695 & 57.9 \\
\hline 17 & Mitz and Peyronie. "The superficial musculo-aponeurotic system (SMAS) in the parotid and cheek area." Plast Reconstr Surg (1976) [24] & 676 & 7.4 \\
\hline 18 & Song et al. "The free thigh flap: a new free flap concept based on the septocutaneous artery." Br J Plast Surg (1984) [25] & 671 & 4.2 \\
\hline 19 & Koshima and Soeda. "Inferior epigastric artery skin flaps without rectus abdominis muscle." Br J Plast Surg (1989) [26] & 669 & 10.4 \\
\hline 20 & Allen and Treece. "Deep inferior epigastric perforator flap for breast reconstruction." Ann Plast Surg (1994) [27] & 665 & 31.1 \\
\hline 21 & Ponten. "The fasciocutaneous flap: its use in soft tissue defects of the lower leg." Br J Plast Surg (1981) [28] & 655 & 14.9 \\
\hline 22 & Soutar et al. "The radial forearm flap: a versatile method for intra-oral reconstruction." Br J Plast Surg (1983) [29] & 654 & 20.1 \\
\hline 23 & Radovan. "Breast reconstruction after mastectomy using the temporary expander." Plast Reconstr Surg (1982) [30] & 625 & 28.5 \\
\hline 24 & Caplan. "The mesengenic process." Clin Plast Surg (1994) [31] & 625 & 16.4 \\
\hline 25 & Ramirez et al. "Components separation" method for closure of abdominal-wall defects: an anatomic and clinical study." Plast Reconstr Surg (1990) [32] & 614 & 9.4 \\
\hline 26 & Zins and Whitaker. "Membranous versus endochondral bone: implications for craniofacial reconstruction." Plast Reconstr Surg (1983) [33] & 609 & 13.9 \\
\hline 27 & $\begin{array}{l}\text { Cao et al. "Transplantation of chondrocytes utilizing a polymer-cell construct to produce tissue-engineered cartilage in the shape of a human ear." } \\
\text { Plast Reconstr Surg (1997) [34] }\end{array}$ & 596 & 36.5 \\
\hline 28 & Mustoe et al. "International clinical recommendations on scar management." Plast Reconstr Surg (2002) [35] & 591 & 36.9 \\
\hline 29 & Coleman "Facial recontouring with lipostructure." Clin Plast Surg (1997) [36] & 585 & 34.0 \\
\hline 30 & Vacanti et al. "Synthetic polymers seeded with chondrocytes provide a template for new cartilage formation." Plast Reconstr Surg & 581 & 28.8 \\
\hline 31 & Daniel and Taylor. "Distant transfer of an island flap by microvascular anastomoses." Plast Reconstr Surg (1973) [38] & 573 & 16.2 \\
\hline 32 & Snyder et al. "Mandibular lengthening by gradual distraction: preliminary report." Plast Reconstr Surg (1973) [39] & 573 & 0.1 \\
\hline 33 & Swartz et al. "The osteocutaneous scapular flap for mandibular and maxillary reconstruction." Plast Reconstr Surg (1986) [40] & 541 & 17.5 \\
\hline 34 & $\begin{array}{l}\text { Neumann. "The expansion of an area of skin by progressive distention of a subcutaneous balloon: use of the method for securing skin for subtotal } \\
\text { reconstruction of the ear." Plast Reconstr Surg (1957) [41] }\end{array}$ & 529 & 9.3 \\
\hline 35 & Muhlbauer et al. "The forearm flap." Plast Reconstr Surg (1982) [42] & 529 & 0.2 \\
\hline 36 & Gray et al. "Embryology for surgeons." Plast Reconstr Surg (1980) [43] & 525 & 13.8 \\
\hline 37 & Laurie et al. "Donor-site morbidity after harvesting rib and iliac bone." Plast Reconstr Surg (1984) [44] & 518 & 10.1 \\
\hline 38 & $\begin{array}{l}\text { Eppley et al. "Platelet quantification and growth factor analysis from platelet-rich plasma: implications for wound healing." Plast Reconstr Surg } \\
\text { (2004) [45] }\end{array}$ & 508 & 50.8 \\
\hline 39 & Illouz. "Body contouring by lipolysis: a 5-year experience with over 3000 cases." Plast Reconstr Surg (1983) [46] & 503 & 10.3 \\
\hline 40 & McGregor and Jackson. "The groin flap." Br J Plast Surg (1972) [47] & 499 & 11.7 \\
\hline 41 & Molina and Ortiz Monasterio. "Mandibular elongation and remodeling by distraction: a farewell to major osteotomies." Plast Reconstr Surg (1995) [48] & 493 & 9.2 \\
\hline 42 & Niessen et al. "On the nature of hypertrophic scars and keloids: a review." Plast Reconstr Surg (1999) [49] & 490 & 32.7 \\
\hline 43 & Sunderland and Williams. "Nerve injuries and their repair: a critical appraisal." Plast Reconstr Surg (1992) [50] & 484 & 21.6 \\
\hline 44 & $\begin{array}{l}\text { Harii et al. "Free gracilis muscle transplantation, with microneurovascular anastomoses for the treatment of facial paralysis: a preliminary report." } \\
\text { Plast Reconstr Surg (1976) [51] }\end{array}$ & 467 & 8.9 \\
\hline 45 & McCraw et al. "Clinical definition of independent myocutaneous vascular territories." Plast Reconstr Surg (1977) [52] & 464 & 17.2 \\
\hline 46 & Holmes. "Bone regeneration within a coralline hydroxyapatite implant." Plast Reconstr Surg (1979) [53] & 462 & 11.9 \\
\hline 47 & Taylor et al. "Superiority of the deep circumflex iliac vessels as the supply for free groin flaps clinical work." Plast Reconstr Surg (1979) [54] & 461 & 13.8 \\
\hline 48 & $\begin{array}{l}\text { Rigotti et al. "Clinical treatment of radiotherapy tissue damage by lipoaspirate transplant: a healing process mediated by adipose-derived adult stem } \\
\text { cells." Plast Reconstr Surg (2007) [55] }\end{array}$ & 458 & 65.4 \\
\hline 49 & Yang et al. "Forearm free skin flap transplantation: a report of 56 cases." Br J Plast Surg (1997) [56] & 449 & 19.1 \\
\hline 50 & Mathes and Nahai. “Classification of the vascular anatomy of muscles: experimental and clinical correlation." Plast Reconstr Surg (1981) [57] & 447 & 7.0 \\
\hline
\end{tabular}


Table 3. Year of publication of top 50 papers

\begin{tabular}{|lc|}
\hline Decade & Number \\
\hline 1950 's & 1 \\
1960 's & 2 \\
1970 's & 10 \\
1980 's & 19 \\
1990 's & 14 \\
2000 's & 4 \\
\hline
\end{tabular}

Table 4. Journals in which the top 50 articles were published

\begin{tabular}{|lc|}
\hline Journal & Number \\
\hline Plastic and Reconstructive Surgery & 36 \\
British journal of plastic surgery & 7 \\
Annals of plastic surgery & 3 \\
Clinics in plastic surgery & 3 \\
Scandinavian Journal of Plastic and Reconstructive Surgery and & 1 \\
$\quad$ Hand Surgery & \\
\hline
\end{tabular}

\section{Table 5. Level of evidence of each of the top 50 papers}

\begin{tabular}{|lc|}
\hline Study type & Number \\
\hline Therapeutic/Experimental & \\
Level 3 & 6 \\
Level 4 & 20 \\
Level 5 & 11 \\
Prognostic & \\
Level 3 & 2 \\
Level 4 & 0 \\
Level 5 & 4 \\
Diagnostic & \\
Level 5 & 7 \\
\hline
\end{tabular}

mon subject matter was reconstruction of acquired defects (18/ $50)$, followed by basic science/experimental research $(9 / 50)$ and craniofacial surgery (7/50) (Table 6).

The top 50 articles came from 12 different countries with the United States (52\%, 26/50) most frequently represented, followed by Australia $(n=5)$ and Sweden $(n=4)$ (Table 7). Seven institutions published more than once in the top 50 articles with Harvard University, University of Melbourne and New York University each with three publications (Table 8). Only one first author (Dr. Taylor) had more than one article in top 50 papers. Taylor et al. [14] had three papers in the top 50 most notably his seminal paper on the free vascularized bone graft in 1975 which has since been cited 1,101 times.

Results from citation index analysis (Table 1) reinforced our selection of top papers with three of the top five remaining in the top five papers based on citation index. Papers which ranked high on citation index was Wei et al. [23] case series describing the anterolateral thigh flap in 2002 (citation index 57.9) and
Table 6. Analvsis of subject matter of the top 50 papers

\begin{tabular}{|lc|}
\hline Subject matter & Number \\
\hline Reconstructive & 18 \\
Basic Science/experimental & 9 \\
Craniofacial & 7 \\
Microsurgery & 5 \\
Fat/aesthetic & 5 \\
Breast & 3 \\
Paediatric/miscellaneous & 3 \\
\hline
\end{tabular}

Table 7. Country of origin of the top 50 articles

\begin{tabular}{|lc|}
\hline Country & Number \\
\hline USA & 26 \\
Australia & 5 \\
Sweden & 4 \\
France & 3 \\
United Kingdom & 2 \\
Taiwan & 2 \\
China & 2 \\
Japan & 2 \\
Canada & 1 \\
Italy & 1 \\
Mexico & 1 \\
Netherlands & 1 \\
\hline
\end{tabular}

Table 8. Institutions with multiple contributions to top 50 papers

\begin{tabular}{|lc|}
\hline Institution & Number \\
\hline Harvard University, USA & 3 \\
University of Melbourne, Australia & 3 \\
New York University, USA & 3 \\
University of Massachusetts, USA & 2 \\
University of Paris, France & 2 \\
Canniesburn Hospital Glasgow, Scotland & 2 \\
Bowman Gray School of Medicine, USA & 2 \\
\hline
\end{tabular}

Rigotti et al. [55] paper describing the use of adipose-derived stem cells for treating radiotherapy wounds in 2007 (citation index 65.4). The mean year of publication for the 10 papers with the highest citation index was $1998 \pm 4$.9 whereas it was 1978 \pm 10.78 for the 10 papers with the lowest citation index.

\section{DISCUSSION}

Our study identifies the top 50 papers published in the plastic surgery from 20 recognized peer-reviewed journals. It provides us with valuable information as to the authors and topics that have had a profound influence on this specialty. Citation analysis was chosen as the determinant of selection. Citation analysis offers an insight to the degree of peer analysis, the readership of 
the article and a measure of peer-recognition [58]. With the lowest number of citations of the top 50 list at 447, every paper on the list can be considered a 'citation classic', far above the frequently used benchmark of 100 citations [59].

In our analysis of level of evidence we have demonstrated that the majority of papers in the top 50 are of levels IV or V, thereby indicating that in plastic surgery research no positive correlation exists between higher number of citations and a high level of evidence. This is echoed in previous studies in plastic surgery [60]. The greater representation of clinical rather than basic science articles reflects the specialty of plastic surgery which places a large emphasis on surgical technique. Basic science research is graded as level $\mathrm{V}$ evidence even though it is often based on sound scientific methodology, and the current classification may create bias against this methodology. An awareness of these top 50 manuscripts, serves as an educational tool to trainees regarding research methodology and ethical considerations [58]. The plastic surgery literature continues to be dominated by lower quality evidence, although this is not shown to affect the attainment of 'classic' status [61].

None of the papers in the top 50 were of evidence level I or II. This is similar to previous papers which showed that only 2.2 percent of articles published in plastic surgery journals are level I evidence [62]. Intersurgeon variability and variation in pathology and anatomy of each patient leads to difficulty in performing randomised control trials or systematic reviews [61]. The large proportion of papers describing variations in reconstruction of a congenital or acquired defect in the top 50 emulates this. Many practical issues provide additional obstacles for use of randomized controlled trials in evaluation of surgical interventions, such as funding, ethics approval, patient recruitment and acceptance, feasibility of performing sham surgery, and technical demands [63]. The diversity of diagnoses and procedures in our specialty and the frequent need to tailor or customize "reconstrucitons" for individual patients further contribute to the difficulty in producing level I evidence [62].

Our study provides an interesting insight into the trends in publications in plastic surgery over time. Papers from the 1950's and 1960's dealt primarily with reconstructive techniques, for example Neumann's [41] paper using a subcutaneous balloon for skin expansion or Bakamjian's [22] paper describing a pectoral flap for pharyngoesophageal reconstruction. The first paper in the top 50 on breast surgery was Hartrampf et al. [15] paper describing the transverse abdominal island flap in 1982. More recent inclusions in the top 50 papers have dealt with the topics of aesthetic surgery and the use of free fat grafting, for example Coleman [36] paper on facial recontouring in 1997. This insight enlightens authors such that a classic paper is a body of work, a novel idea or innovation that has an enduring effect on our daily practice [3]. This trend in terms of subject matter allows us to postulate likely contributions in the near future to classic papers. Papers focussing on the use of free fat grafting has undergone a growing focus in the recent past, with papers such as 'Structural fat grafting: more than a permanent filler' by Coleman [64] in 2006 narrowly missing out on our current top 50 list.

The discipline of plastic surgery has long contributed to cutting-edge research and innovation. To produce higher level research, plastic surgery as a specialty must aim higher than to publish descriptions of clinical experience. A common problem in plastic surgical literature relates to an inadequate power of the study to detect a difference in treatment groups, usually because of insufficient numbers of subjects. An upward trend in the quality of evidence was observed over the last 10 years, particularly in the amount of level 2 and 3 evidence produced [63].

The authors recognise some limitations to this type of study. We restricted our search to the plastic surgery literature. In the area of plastic surgery, there have been frequently cited papers published that have appeared outside of these journals. One example is Gabriel et al. [65] paper describing connective tissue disorders following breast implantation published in The New England Journal of Medicine in 1994. This paper has had great influence in the history of plastic surgery even though it was not published in a plastic surgery journal. High impact journals are lacking in plastic surgery. This creates a disadvantage to the specialty in cases where attainment of grants or peer recognition is often on the basis of impact factor alone. This is why plastic surgeons often publish their work in high-impact journals of related research fields [7]. This may lead to essential evidence, required for daily practice in our specialty, no longer being published in our own journals.

A further limitation of the present study is the clinical bias associated with the ranking scale. The level-of-evidence scale used is specifically designed to assess clinical level of evidence and to reward articles with the most robust and clinically relevant studies [62]. Therefore basic science research is ranked as level 5 despite the majority of these studies having sound research methodology. Furthermore, they may be the only research design that is feasible to address a particular clinical question [66]. The evidence-based scale may be particularly problematic for plastic surgery because of the tradition of publishing articles that demonstrate ingenuity, for example, the description of a new technique [61].

Use of citation analysis carries with it inherent flaws. Firstly, it does not account for self-citation, in-house bias, journal bias, powerful person bias or omission bias by purposely not citing competitors [67]. Secondly, citation analysis ignores the fact of 
a citation being positive or negative. There is a clear time-effect bias in citation analysis which puts more recent articles at a disadvantage. To overcome this bias, we calculated the citation index of each of the top 50 articles to further assess our choice. We found that use of citation index favoured more recent papers, which is not surprising considering older papers have an overall tendency to be cited less frequently. The increasing use of reference managers (e.g., EndNote, Thomson Reuters, NY, USA) and the availability of many journal online, especially with open access, has eased the citation process for authors [68].

Although the total number of citations is a valuable insight of the impact on a given subject, it is not always a true reflection. Taylor and Daniel [69] featured three times in the top 50 papers however his seminal paper describing the free flap in 1973 has only been cited 88 times. Past research showed that, as time passes, even "true classics" are gradually cited less often because their substance has been consumed by the current knowledge, by a phenomenon of "obliteration by incorporation" [70].

In conclusion, evidence-based medicine has increasingly become an integral part of clinical research and practice. Citation analysis is not a direct indicator of scientific quality. However, the more times a paper is cited reflects its impact on the specialty and its peers. The top 50 list highlights the leading papers in the field of plastic and reconstructive surgery. In the plastic surgery literature, no positive correlation exists between a high number of citations and a high level of evidence. Anatomical reconstructive challenges tend to be the main focus of plastic surgery rather than pathologic diseases and consequently, papers with lower levels of evidence are relatively more valuable in plastic surgery than many other specialties.

\section{REFERENCES}

1. Sackett DL, Rosenberg WM, Gray JA, et al. Evidence based medicine: what it is and what it isn't. BMJ 1996;312:71-2.

2. Seglen PO. Why the impact factor of journals should not be used for evaluating research. BMJ 1997;314:498-502.

3. Kelly JC, Glynn RW, O’Briain DE, et al. The 100 classic papers of orthopaedic surgery: a bibliometric analysis. J Bone Joint Surg Br 2010;92:1338-43.

4. Paladugu R, Schein M, Gardezi S, et al. One hundred citation classics in general surgical journals. World J Surg 2002;26: 1099-105.

5. Heldwein FL, Rhoden EL, Morgentaler A. Classics of urology: a half century history of the most frequently cited articles (1955-2009). Urology 2010;75:1261-8.

6. Phillips B, Ball C, Sackett D, et al. Levels of evidence and grades of recommendation [Internet]. Oxford: Centre for
Evidence Based Medicine; 2001 [cited 2015 May 10]. Available from: http://www.cebm.net/levels_of_evidence.asp.

7. Loonen MP, Hage JJ, Kon M. Value of citation numbers and impact factors for analysis of plastic surgery research. Plast Reconstr Surg 2007;120:2082-91.

8. Mulliken JB, Glowacki J. Hemangiomas and vascular malformations in infants and children: a classification based on endothelial characteristics. Plast Reconstr Surg 1982;69:41222.

9. Argenta LC, Morykwas MJ. Vacuum-assisted closure: a new method for wound control and treatment: clinical experience. Ann Plast Surg 1997;38:563-76.

10. Morykwas MJ, Argenta LC, Shelton-Brown EI, et al. Vacuum-assisted closure: a new method for wound control and treatment: animal studies and basic foundation. Ann Plast Surg 1997;38:553-62.

11. McCarthy JG, Schreiber J, Karp N, et al. Lengthening the human mandible by gradual distraction. Plast Reconstr Surg 1992;89:1-8.

12. Branemark PI, Adell R, Breine U, et al. Intra-osseous anchorage of dental prostheses. I. Experimental studies. Scand J Plast Reconstr Surg 1969;3:81-100.

13. Masquelet AC, Romana MC, Wolf G. Skin island flaps supplied by the vascular axis of the sensitive superficial nerves: anatomic study and clinical experience in the leg. Plast Reconstr Surg 1992;89:1115-21.

14. Taylor GI, Miller GD, Ham FJ. The free vascularized bone graft: a clinical extension of microvascular techniques. Plast Reconstr Surg 1975;55:533-44.

15. Hartrampf CR, Scheflan M, Black PW. Breast reconstruction with a transverse abdominal island flap. Plast Reconstr Surg 1982;69:216-25.

16. Taylor GI, Palmer JH. The vascular territories (angiosomes) of the body: experimental study and clinical applications. $\mathrm{Br}$ J Plast Surg 1987;40:113-41.

17. Hidalgo DA. Fibula free flap: a new method of mandible reconstruction. Plast Reconstr Surg 1989;84:71-9.

18. Ariyan $S$. The pectoralis major myocutaneous flap: a versatile flap for reconstruction in the head and neck. Plast Reconstr Surg 1979;63:73-81.

19. Godina M. Early microsurgical reconstruction of complex trauma of the extremities. Plast Reconstr Surg 1986;78:28592.

20. Dahlin C, Linde A, Gottlow J, et al. Healing of bone defects by guided tissue regeneration. Plast Reconstr Surg 1988;81: 672-6.

21. Bain JR, Mackinnon SE, Hunter DA. Functional evaluation of complete sciatic, peroneal, and posterior tibial nerve le- 
sions in the rat. Plast Reconstr Surg 1989;83:129-38.

22. Bakamjian VY. A two-stage method for pharyngoesophageal reconstruction with a primary pectoral skin flap. Plast Reconstr Surg 1965;36:173-84.

23. Wei FC, Jain V, Celik N, et al. Have we found an ideal softtissue flap? An experience with 672 anterolateral thigh flaps. Plast Reconstr Surg 2002;109:2219-26.

24. Mitz V, Peyronie M. The superficial musculo-aponeurotic system (SMAS) in the parotid and cheek area. Plast Reconstr Surg 1976;58:80-8.

25. Song YG, Chen GZ, Song YL. The free thigh flap: a new free flap concept based on the septocutaneous artery. Br J Plast Surg 1984;37:149-59.

26. Koshima I, Soeda S. Inferior epigastric artery skin flaps without rectus abdominis muscle. Br J Plast Surg 1989;42:645-8.

27. Allen RJ, Treece P. Deep inferior epigastric perforator flap for breast reconstruction. Ann Plast Surg 1994;32:32-8.

28. Ponten B. The fasciocutaneous flap: its use in soft tissue defects of the lower leg. Br J Plast Surg 1981;34:215-20.

29. Soutar DS, Scheker LR, Tanner NS, et al. The radial forearm flap: a versatile method for intra-oral reconstruction. Br J Plast Surg 1983;36:1-8.

30. Radovan C. Breast reconstruction after mastectomy using the temporary expander. Plast Reconstr Surg 1982;69:195208.

31. Caplan AI. The mesengenic process. Clin Plast Surg 1994; 21:429-35.

32. Ramirez OM, Ruas E, Dellon AL. "Components separation” method for closure of abdominal-wall defects: an anatomic and clinical study. Plast Reconstr Surg 1990;86:519-26.

33. Zins JE, Whitaker LA. Membranous versus endochondral bone: implications for craniofacial reconstruction. Plast Reconstr Surg 1983;72:778-85.

34. Cao Y, Vacanti JP, Paige KT, et al. Transplantation of chondrocytes utilizing a polymer-cell construct to produce tissue-engineered cartilage in the shape of a human ear. Plast Reconstr Surg 1997;100:297-302.

35. Mustoe TA, Cooter RD, Gold MH, et al. International clinical recommendations on scar management. Plast Reconstr Surg 2002;110:560-71.

36. Coleman SR. Facial recontouring with lipostructure. Clin Plast Surg 1997;24:347-67.

37. Vacanti CA, Langer R, Schloo B, et al. Synthetic polymers seeded with chondrocytes provide a template for new cartilage formation. Plast Reconstr Surg 1991;88:753-9.

38. Daniel RK, Taylor GI. Distant transfer of an island flap by microvascular anastomoses: a clinical technique. Plast Reconstr Surg 1973;52:111-7.
39. Snyder CC, Levine GA, Swanson HM, et al. Mandibular lengthening by gradual distraction: preliminary report. Plast Reconstr Surg 1973;51:506-8.

40. Swartz WM, Banis JC, Newton ED, et al. The osteocutaneous scapular flap for mandibular and maxillary reconstruction. Plast Reconstr Surg 1986;77:530-45.

41. Neumann CG. The expansion of an area of skin by progressive distention of a subcutaneous balloon; use of the method for securing skin for subtotal reconstruction of the ear. Plast Reconstr Surg (1946) 1957;19:124-30.

42. Muhlbauer W, Herndl E, Stock W. The forearm flap. Plast Reconstr Surg 1982;70:336-44.

43. Gray SW, Skandalakis J, Achauer BM. Embryology for surgeons. Plast Reconstr Surg 1980;65:528.

44. Laurie SW, Kaban LB, Mulliken JB, et al. Donor-site morbidity after harvesting rib and iliac bone. Plast Reconstr Surg 1984;73:933-8.

45. Eppley BL, Woodell JE, Higgins J. Platelet quantification and growth factor analysis from platelet-rich plasma: implications for wound healing. Plast Reconstr Surg 2004;114:1502-8.

46. Illouz YG. Body contouring by lipolysis: a 5-year experience with over 3000 cases. Plast Reconstr Surg 1983;72:591-7.

47. McGregor IA, Jackson IT. The groin flap. Br J Plast Surg 1972; 25:3-16.

48. Molina F, Ortiz Monasterio F. Mandibular elongation and remodeling by distraction: a farewell to major osteotomies. Plast Reconstr Surg 1995;96:825-40.

49. Niessen FB, Spauwen PH, Schalkwijk J, et al. On the nature of hypertrophic scars and keloids: a review. Plast Reconstr Surg 1999; 104:1435-58.

50. Sunderland SS, Williams HB. Nerve injuries and their repair: a critical appraisal. Plast Reconstr Surg 1992;89:1170.

51. Harii K, Ohmori K, Torii S. Free gracilis muscle transplantation, with microneurovascular anastomoses for the treatment of facial paralysis: a preliminary report. Plast Reconstr Surg 1976;57:133-43.

52. McCraw JB, Dibbell DG, Carraway JH. Clinical definition of independent myocutaneous vascular territories. Plast Reconstr Surg 1977;60:341-52.

53. Holmes RE. Bone regeneration within a coralline hydroxyapatite implant. Plast Reconstr Surg 1979;63:626-33.

54. Taylor GI, Townsend P, Corlett R. Superiority of the deep circumflex iliac vessels as the supply for free groin flaps: clinical work. Plast Reconstr Surg 1979;64:745-59.

55. Rigotti G, Marchi A, Galie M, et al. Clinical treatment of radiotherapy tissue damage by lipoaspirate transplant: a healing process mediated by adipose-derived adult stem cells. Plast Reconstr Surg 2007;119:1409-22. 
56. Yang GF, Chen PJ, Gao YZ, et al. Forearm free skin flap transplantation: a report of 56 cases. 1981. Br J Plast Surg 1997; 50:162-5.

57. Mathes SJ, Nahai F. Classification of the vascular anatomy of muscles: experimental and clinical correlation. Plast Reconstr Surg 1981;67:177-87.

58. Nason GJ, Tareen F, Mortell A. The top 100 cited articles in urology: an update. Can Urol Assoc J 2013;7:E16-24.

59. Lefaivre KA, Shadgan B, O’Brien PJ. 100 most cited articles in orthopaedic surgery. Clin Orthop Relat Res 2011;469: 1487-97.

60. Loonen MP, Hage JJ, Kon M. Plastic Surgery Classics: characteristics of 50 top-cited articles in four Plastic Surgery Journals since 1946. Plast Reconstr Surg 2008;121:320e-327e.

61. Loiselle F, Mahabir RC, Harrop AR. Levels of evidence in plastic surgery research over 20 years. Plast Reconstr Surg 2008;121:207e-211e.

62. Sinno H, Neel OF, Lutfy J, et al. Level of evidence in plastic surgery research. Plast Reconstr Surg 2011;127:974-80.

63. Xu CC, Cote DW, Chowdhury RH, et al. Trends in level of evidence in facial plastic surgery research. Plast Reconstr Surg 2011;127:1499-504.

64. Coleman SR. Structural fat grafting: more than a permanent filler. Plast Reconstr Surg 2006;118:108s-120s.

65. Gabriel SE, O’Fallon WM, Kurland LT, et al. Risk of connective-tissue diseases and other disorders after breast implantation. N Engl J Med 1994;330:1697-702.

66. Chung KC, Ram AN. Evidence-based medicine: the fourth revolution in American medicine? Plast Reconstr Surg 2009; 123:389-98.

67. Cheek J, Garnham B, Quan J. What's in a number? Issues in providing evidence of impact and quality of research(ers). Qual Health Res 2006; 16:423-35.

68. Lawrence S. Free online availability substantially increases a paper's impact. Nature 2001;411:521.

69. Taylor GI, Daniel RK. The free flap: composite tissue transfer by vascular anastomosis. Aust N Z J Surg 1973;43:1-3.

70. Chuang KY, Ho YS. A bibliometric analysis on top-cited articles in pain research. Pain Med 2014;15:732-44. 